\title{
Myrmecia israeliensis as the primary symbiotic microalga in squamulose lichens growing in European and Canary Island terricolous communities
}

\author{
Patricia MoyA ${ }^{1}$, Salvador Chiva ${ }^{1}$, Aránzazu Molins ${ }^{1}$, Iva JADRná2, Pavel ŠKaloud ${ }^{2}$, \\ Ondřej PeKsa $^{3}$ \& Eva Barreno ${ }^{1}$
}

\author{
${ }^{1}$ Universitat de València, Fac. CC. Biológicas, ICBIBE, Botánica. C/ Dr. Moliner 50, 46100-Burjassot, Valencia, \\ Spain; *Corresponding authore-mail: patricia.moya@uv.es \\ ${ }^{2}$ Charles University in Prague, Faculty of Sciences, Department of Botany, Benátská 2, 12801 Praha 2, Czech \\ Republic \\ ${ }^{3}$ The West Bohemian Museum in Pilsen, Kopeckého sady 2, 30100-Plzeñ, Czech Republic
}

\begin{abstract}
Myrmecia israeliensis has been traditionally considered as a green coccoid free-living microalga. This microalga was previously suggested as the primary phycobiont in the lichens Placidium spp., Heteroplacidium spp., and Psora decipiens. However, due to the absence of ITS rDNA sequences (barcode information) published along with these investigations, the symbiotic nature of $M$. israeliensis might be confirmed by using the DNA barcoding and different microscopic examinations both in the symbiotic state and in culture. The aim of this study was to settle the presence of $M$. israeliensis as the primary microalga in squamulose lichens growing in terricolous communities (Psora spp., Placidium spp. and Claviscidium spp.) in 32 localities within European and Canary Island ecosystems by using both molecular and ultrastructural techniques. The lichen-forming fungi were identified using ITS rDNA as a barcode, and in the case of $P$. decipiens specimens, the mycobiont analyses showed an unexpected variability. Phycobiont phylogenetic analyses were made using both chloroplast (LSU rDNA) and nuclear (ITS rDNA) molecular markers. Our results proved that $M$. israeliensis is the primary symbiotic microalga in all the chosen and analyzed lichens. In addition, fluorescence microscopy, transmission electron microscopy and scanning electron techniques were used to characterize $M$. israeliensis. Finally, the presence of this microalga in lichen thalli was verified using different microscopic observations. A combination of different techniques, both molecular and microscopic, allowed for the accurate identification of this symbiotic microalga, beforehand mainly known as free living. Here, we suggest the combination of these techniques to prevent incorrect identification in microalgal lichen studies.
\end{abstract}

Key words: Clavascidium spp., ITS rDNA (barcoding), LSU rDNA, Myrmecia israeliensis, phycobiont, Placidium spp., Psora spp., ultrastructure

\section{INTRODUCTION}

The dynamics and ecology of biological soils crusts (BSC) in arid and semiarid regions of the world have been well documented over the last decade (BELNAP 2003; Maestre et al. 2011; Pointing \& Belnap 2012; Weber et al. 2016). Recently, the European research initiative "Soil Crust International" (SCIN) focused on the relevance of the biodiversity of BSC and the functional aspects in their specific environment (BÜDEL et al. 2014; BELNAP \& BÜDEL 2016).

Many lichen species are adapted to dry environments and are components of BSC in semiarid regions, and they play an important role in the functioning of these ecosystems (BELNAP \& LANGE 2001; ROSENTRETER 2007; BowKer et al. 2011; BeLnAP \& BÜDEL 2016). In particular, terricolous squamulose lichens, such as Psora decipiens (Hedwig) Hoffm. and P. saviczii (Tomin) Follmann et A. CRespo, form a compact and stable zone in the upper millimeters of the substratum (BelnAP \& LANGE 2001), and the occurrence of these pioneer lichens is dependent on their phycobiont availability. The microalgae pool is crucial to settle these communities, and points out the relevance of studying the algal diversity; however, phycobiont identification in several Psora spp. has been controversial.

The primary phycobiont of $P$. decipiens and $P$. globifera (ACH.) A. MASSAL has been identified as Myrmecia biatorellae (Tschermak-Woess et Pessl) Petersen (Geitler 1963; Galun et al. 1971; TschermaK-Woess 1988), although SCHAPER \& OTT (2003) claimed to have found a species of Asterochloris in P. decipiens. RUPRECHT et al. (2014) associated P. decipiens from Spanish and North and Central European localities with several 
species mostly belonging to the genera Asterochloris and Trebouxia. Recently, WiLliams et al. (2017) suggested the green algal genus Myrmecia as the primary phycobiont in $P$. decipiens, but their analyses were based only on $26 \mathrm{~S}$ rDNA and $r b c \mathrm{~L}$ molecular markers and no ITS rDNA information was provided.

M. biatorellae and $M$. israeliensis (CHANTANACHAT et BOLD) T. FRIEDL have also been found associated with a lineage in the lichen family Verrucariaceae (THüs et al. 2011). Representatives of this family, such as Placidium spp. and Heteroplacidium spp., are also associated with BSC and share with Psora spp. their terricolous squamulose appearance worldwide (TSCHERMAK-WOESS 1988; FRIEDL \& BÜDEL 2008).

The diversity, ecology, and distribution of the genus Myrmecia as a lichen phycobiont have been overlooked in the past, and some interesting questions about this genus are still unresolved. The aim of this study was to settle the presence of $M$. israeliensis as the primary phycobiont in different terricolous squamulose lichen species (Psora spp., Placidium spp. and Claviscidium spp.) growing on xerothermic soil crusts by using both molecular (DNA barcoding) and ultrastructural techniques, in 32 localities within European and Canary Island ecosystems.

\section{Material ANd Methods}

Lichen material. Psora decipiens $(\mathrm{n}=31)$, Psora saviczii $(\mathrm{n}=$ 7), Placidium pilosellum (Breuss) Breuss $1(\mathrm{n}=4)$ ), Placidium sp. $1(\mathrm{n}=2)$, Placidium sp. $2(\mathrm{n}=4)$, Clavascidium sp. $2(\mathrm{n}=$ $3)$ and Clavascidium sp. $3(n=1)$ were collected from 32 locations within Europe and the Canary Islands (Table 1 and Supplementary Table 1). Samples were dried and stored at $-20{ }^{\circ} \mathrm{C}$ until processing.

Sample preparation. Lichen squamules were examined under a stereo-microscope to remove surface contamination (e.g. sand, mosses, epiphytic algae, fragments of other lichen species, or infection by lichenicolous fungi). The squamules were sterilized by sequential immersion in $96 \%$ ethanol (10 s), $0.5 \% \mathrm{NaOCl}(2 \mathrm{~min})$ and $70 \%$ ethanol ( $2 \mathrm{~min}$ ) (ARNOLD et al. 2009). Two to five squamules from each location were randomly selected and pooled together.

DNA extraction, amplification and sequencing. Total genomic DNA of the Iberian Peninsula and Canary Islands samples (IB_CI) as well as from free-living microalgae inside saccharoid gypsum crystals from Madrid Province (collected from rock faces in the same location as the lichen samples), was isolated and purified using the DNeasy TM Plant Mini kit (Qiagen, Hilden, Germany) following the manufacturer's instructions. The standard CTAB protocol (Doyle \& DoyLE 1987) was performed in the remaining samples from North and Central Europe (N_CE).

The mycobiont and primary phycobiont (both from thalli and/or from isolated culture) were identified by Sanger sequencing. Fungal ITS rDNA was amplified using the primer pair ITS1F (GARDES \& BRUNS 1993) and ITS4 (White et al. 1990). Two algal loci were amplified; a region of the chloroplast LSU rDNA gene using the algal-specific primers 23SU1 and
23SU2 (Del CAMPo et al. 2010) and the ITS rDNA. The ITS rDNA was amplified using the two specific primer pairs. The first combination consisted of two specific primers designed based on the M. israeliensis sequence, MI F (5'- GCC CGT TGT TGC CCT TCA-3', located in the ITS1 region) + MI_R (5'-CAG TAT GTC ACA ACA GGC CA-3', located in the ITS2 region). The second combination included the newly designed primer specific to green algae zeleny_F2 (5'-TTC TTA GTT GGT GGG TTG CC-3', located at the end of 18S rDNA) + the universal primer ITS4 (White et al. 1990), respectively. In the IB_CI samples, PCR reactions and Sanger sequencing were performed as described in Molins et al. (2017). In the N CE samples, PCRs were performed in $20 \mu \mathrm{l}$ using MyTaq $^{\mathrm{TM}}$ DNA polymerase (Bioline, London, UK) containing: $4 \mu \mathrm{m}$ of buffer, $0,3 \mu \mathrm{m}$ zeleny_F2/ITS4 primers, $0,2 \mu \mathrm{m}$ MyTaq polymerase and $1 \mu \mathrm{l}$ of template DNA.Sterile Milli-Q water was used to bring to volume. The PCR program for amplification comprised of an initial denaturation at $94^{\circ} \mathrm{C}$ for $4 \mathrm{~min}$, and 35 cycles at $94{ }^{\circ} \mathrm{C}$ for $60 \mathrm{~s}, 56^{\circ} \mathrm{C}$ for $60 \mathrm{~s}$ and $72{ }^{\circ} \mathrm{C}$ for $90 \mathrm{~s}$, followed by a final elongation at $72{ }^{\circ} \mathrm{C}$ for $10 \mathrm{~min}$. Amplifications were carried out on a 96-well labcyclers SensoQuest (Progen Scientific Ltd., South Yorkshire, UK) or Mastercycler gradient (Eppendrorf). The PCR products were visualized on $0.8 \%$ agarose gels and purified using MagJET Magnetic Bead-Based Nucleic Acid Purification (ThermoFischer Scientific, Massachusetts, USA). All the Sanger sequencing experiments were performed at Macrogen Inc. (Seoul, Korea).

Sequence analyses. Phycobiont phylogenetic analysis. A multiple alignment was prepared including: i) the newly determined algal ITS rDNA (KY981643 to KY981701) and LSU rDNA (KY981702 to KY981749) sequences from the lichen thalli, the cultures and the gypsum crystals, ii) a selection of Trebouxia, Myrmecia and Asterochloris species available from the Culture Collection of Algae at Göttingen University (SAG), from the Culture Collection of Algae at the University of Texas (UTEX) and from Culture Collection of Algae at the University of Prague (CAUP) downloaded from the GenBank, and iii) selected Chlorophyta ITS rDNA sequences obtained by RUPRECHT et al. (2014). The alignment was carried out using MAFFT v 7.0 (КАTOH et al. 2002; КATOH \& STANDLEY 2013) with default parameters, visualized and manually adjusted. GBlocks 0.91b (CASTRESANA 2000) was used to remove ambiguously aligned regions and large gaps by means of a less stringent option allowing smaller final blocks and gap positions within the final blocks. Alignment was $1237 \mathrm{bp}$ in length for the ITS rDNA+LSU rDNA region. The best-fit substitution model for this alignment $(\mathrm{GTR}+\mathrm{I}+\mathrm{G})$ was chosen using jModelTest v 2.0 (DARRIBA et al. 2012) and applying the Akaike Information Criterion (AKAIKe 1974, 2011). Maximum Likelihood (ML) analysis was implemented in RAxML v 8.1.11 (StAMATAKIS 2014) using the GTRCAT substitution model. Bootstrap support was calculated based on 1,000 replications (STAMATAKIS et al. 2008). Bayesian phylogenetic analyses were carried out in MrBAYES v 3.2 (RoNQUIST et al. 2012). Settings included two parallel runs with six chains over 20 million generations starting with a random tree, and sampling after every $200^{\text {th }}$ step. We discarded the first $25 \%$ of data as burn-in. MAFFT, jModelTest, ML and Bayesian analyses were implemented at the CIPRES Science Gateway v 3.3 webportal (Miller et al. 2010). Phylogenetic trees were visualized in FigTree v 1.4.1 (RAMBAut 2014).

Mycobiont phylogenetic analysis. Two multiple alignments were prepared. The first one included the newly determined 
Table 1. Location for collections of Psora spp., Claviscidium spp. and Placidium spp. samples used in this study.

\begin{tabular}{|c|c|c|}
\hline $\begin{array}{l}\text { Locality/geographic coordinates/altitude/bioclimatic belt/collection } \\
\text { data }\end{array}$ & Type of substrate & $\begin{array}{l}\text { Sample } \\
\text { code }\end{array}$ \\
\hline $\begin{array}{l}\text { Spain, Asturias, Puerto Somiedo, Puerto/ } 43^{\circ} 02^{\prime} 23^{\prime \prime N}, 06^{\circ} 14^{\prime} 29^{\prime \prime} \mathrm{W} \\
\text { / 1250/ Upper supratemp submediterranean low hyperhumid / leg. } \\
\text { Vázquez \& Fernández 04/10/2014 }\end{array}$ & Limestone, calcareous & AST \\
\hline $\begin{array}{l}\text { Spain, León, Rabanal de Luna, Ermita de la Virgen de Pruneda/ } \\
42^{\circ} 56^{\prime} 17 " N, 05^{\circ} 58^{\prime} 25^{\prime \prime} \text { / 1150/ Upper supratemp submediterranean } \\
\text { upper humid / leg. Vázquez 27/09/2014 }\end{array}$ & Limestone, calcareous & LEN \\
\hline $\begin{array}{l}\text { Spain, Madrid, Fuentidueña de Tajo/ } 40^{\circ} 07^{\prime} 41^{\prime \prime N}, 03^{\circ} 09^{\prime} 14^{\prime \prime W} / 571 / \\
\text { Upper mesomediterranean low dry / leg. Barreno, Chiva, Molins \& } \\
\text { Salvà 24/02/2012 }\end{array}$ & Miocene gypsum & MAD_FT \\
\hline $\begin{array}{l}\text { Spain, Madrid, Titulcia/ } 40^{\circ} 07^{\prime} 32^{\prime \prime N}, 03^{\circ} 33^{\prime} 15^{\prime \prime W} / 521 / \text { Upper } \\
\text { mesomediterranean low dry / leg. Barreno, Chiva, Molins \& Salvà } \\
24 / 02 / 2012\end{array}$ & Miocene gypsum & $\begin{array}{l}\text { MAD_ } \\
\text { TIL }\end{array}$ \\
\hline $\begin{array}{l}\text { Spain, Zaragoza, Pina de Ebro/ } 41^{\circ} 29^{\prime} 29^{\prime \prime N}, 0^{\circ} 15^{\prime} 30^{\prime \prime} \mathrm{W} / 351 / \text { Upper } \\
\text { mesomediterranean low dry / leg. Barreno, Chiva, Moya \& Salvà } \\
\text { 14/11/2014 }\end{array}$ & Miocene gypsum & ZGZ \\
\hline $\begin{array}{l}\text { Spain, Almería, Sorbas } / 37^{\circ} 08^{\prime} 44^{\prime \prime N}, 02^{\circ} 08^{\prime} 43^{\prime \prime W} / 415 / \text { Upper } \\
\text { thermomediterranean low semiarid / leg. Barreno, Chiva, Moya \& Salvà } \\
09 / 01 / 2014\end{array}$ & Miocene gypsum & ALM \\
\hline $\begin{array}{l}\text { Spain, Alicante, Villena/ } 38^{\circ} 39^{\prime} 26^{\prime \prime} \mathrm{N}, 0^{\circ} 56^{\prime} 13^{\prime \prime W} / 518 / \text { Upper } \\
\text { mesomediterranean low dry / leg. Barreno, Chiva, Moya \& Salvà } \\
11 / 01 / 2014\end{array}$ & Miocene gypsum & ALC \\
\hline $\begin{array}{l}\text { Spain, Cádiz, El Gastor, Ventas Nuevas/ 36 } 50^{\circ} 08^{\prime N} \text {, 05²0'55"W / 461/ } \\
\text { Low subhumid / leg. Chiva 07/09/2016 }\end{array}$ & Triassic gypsum & CAD \\
\hline $\begin{array}{l}\text { Spain, Málaga: Ronda, P. Nat. de la Sierra de las Nieves, Cañada de las } \\
\text { Ánimas/ 36002'13"N, } 05^{\circ} 01^{\prime} 09^{\prime \prime} \mathrm{W} / 1459 / \text { Upper supramediterranean } \\
\text { low humid / leg. Chiva 09/09/2016 }\end{array}$ & Limestones, calcareous & MLG \\
\hline $\begin{array}{l}\text { Spain, Cataluña, Lleida, Ponts Guisona/ } 41^{\circ} 52^{\prime} 45^{\prime \prime N}, 01^{\circ} 13^{\prime} 15^{\prime \prime E} / 382 / \\
\text { Low supramediterranean low subhumid / leg. Salvà } 15 / 12 / 2012\end{array}$ & Oligocene gypsum & CAT \\
\hline $\begin{array}{l}\text { Spain, Lanzarote, Orzola/ } 29^{\circ} 13^{\prime} 20^{\prime \prime} \mathrm{N}, 13^{\circ} 27^{\prime} 10^{\prime \prime} \mathrm{W} / 9 / \\
\text { Inframediterranean arid / leg. Barreno \& Molins 24/11/2013 }\end{array}$ & Volcanic & LNZ \\
\hline $\begin{array}{l}\text { Spain, Valencia, Algar de Palancia/ } 39^{\circ} 46^{\prime} 12^{\prime \prime N}, 0^{\circ} 23^{\prime} 18^{\prime \prime} \mathrm{W} / 208 / \text { Upper } \\
\text { thermomediterranean low dry / leg. Barreno \& Salvà 8/05/2013 }\end{array}$ & Limestones, calcareous & VLC \\
\hline $\begin{array}{l}\text { Czech Republic, Nové Dobrkovice, Český Krumlov/ 4849'09"N, } \\
14^{\circ} 17^{\circ} 32^{\prime \prime E} / 521 / \text { Upper supratemperate low humid/ leg. Jadrná } \\
21 / 09 / 2015\end{array}$ & Metamorphic limestone & $\mathrm{NOV}$ \\
\hline $\begin{array}{l}\text { Czech Republic, Beroun, Merhout‘s rock/ } 49^{\circ} 57^{\prime} 26 " \mathrm{~N}, 14^{\circ} 05^{\prime} 50^{\prime \prime E} / \\
\text { 250-260/ Upper supratemperate low subhumid / leg. Peksa \& Jadrná } \\
\text { 11/08/2014 }\end{array}$ & Diabase calcareous & BER \\
\hline 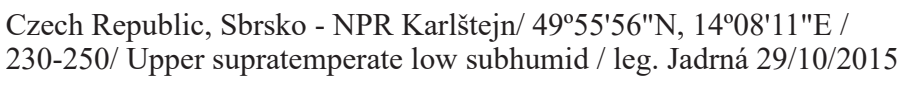 & Devonian Limestones, calcareous & SBR \\
\hline $\begin{array}{l}\text { Turkey, Akseki/ } 38^{\circ} 38^{\prime} 42^{\prime \prime N}, 34^{\circ} 50^{\prime} 05^{\prime \prime E} / 1228 / \text { Upper } \\
\text { supramediterranean upper dry/ leg. Jadrná 14/05/2015 }\end{array}$ & Limestones, calcareous & TUK \\
\hline 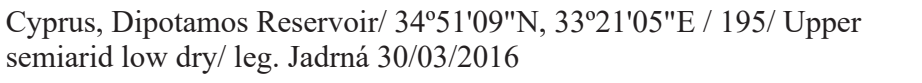 & Miocene gypsum & DIP \\
\hline $\begin{array}{l}\text { Cyprus, Avkas gorge/ } 34^{\circ} 55^{\prime} 26^{\prime \prime} \mathrm{N}, 32^{\circ} 20^{\prime} 32^{\prime \prime} \mathrm{E} / 85 / \text { Low } \\
\text { thermomediterranean low dry/ leg. Jadrná 30/03/2016 }\end{array}$ & Limestones, calcareous & AVK \\
\hline $\begin{array}{l}\text { Cyprus, Akamas peninsula, Neo Chorio/ } 35^{\circ} 03^{\prime} 02^{\prime \prime N}, 32^{\circ} 21^{\prime} 16^{\prime \prime} \mathrm{E} / 12 / \\
\text { Low thermomediterranean low dry/ leg. Jadrná } 30 / 03 / 2016\end{array}$ & Miocene gypsum & AKA \\
\hline $\begin{array}{l}\text { Cyprus, Akrotiri/ } 34^{\circ} 36^{\prime} 03^{\prime \prime N}, 32^{\circ} 58^{\prime} 15^{\prime \prime} \mathrm{E} / 1 / \text { Upper inframediterranean } \\
\text { low dry/ leg. Jadrná 30/03/2016 }\end{array}$ & Limestones, calcareous & AKR \\
\hline
\end{tabular}


Table 1 Cont

Cyprus, Akrotiri 2/ 34³6'01"N, 32058'21"E / 1/ Upper

Limestones, calcareous

AKR_2

inframediterranean low dry / leg. Jadrná 30/03/2016

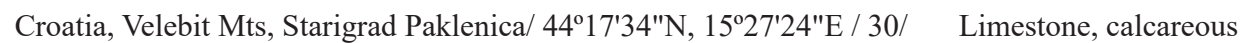

STA

Low mesomediterranean low subhumid/ leg. Malíček 28/06/2016

Germany, ruine Homburg/ 5001'38"N, 09²7'58"E / 300/ Low

supratemperate upper subhumid/ leg. Peksa, Jadrná 7/11/2014

Triassic, calcareous

$\mathrm{HOM}$

Slovakia, Tematín, Lúka, Považský Inovec/ 4840'03"N, 1754'57"E /

350/ Low supratemperate upper subhumid / leg. Peksa 13/4/2015

Wetterstein dolomite, calcareous

TEM

Slovakia, Lúka 1, Považský Inovec/ 48³9'43"N, 1753'37"E / 221/ Low supratemperate upper subhumid / leg. Jadrná 11/10/2016

Slovakia, Lúka 2, Považský Inovec/ 4840'03"N, 1754'54"E / 337/ Low supratemperate upper subhumid / leg. Jadrná 11/10/2016

Slovakia, Za Šípem, Stankovany/ 4909'54"N, 19¹0'23"E / 1092/ Loew orotemperate upper humid/ leg. Jadrná 11/10/2016

Slovakia, Turnianský hradný vrch/4836'35"N, 2052'34"E / 319/ Low supratemperate low humid/ leg. Jadrná 11/01/2016

Slovakia, Lančár/ 48³5'58"N, 17³8'49"E / 247/ Low supratemperate upper subhumid/ leg. Jadrná 11/01/2016

Slovakia, Pustá Ves/ 48³8'28"N, 17³6'48"E / 295/ Low supratemperate upper subhumid / leg. Jadrná 11/01/2016

Slovakia, Velký Plešivec/ 4842'05"N, 1744'12"E / 465/ Low supratemperate low humid/ leg. Jadrná 11/01/2016

Slovakia, Dolný Lopašov/ 48³5'18"N, 17³8'02"E / 250/ Low supratemperate upper subhumid/ leg. Jadrná 11/01/2016

Wetterstein dolomite, calcareous

LUK_1

Wetterstein dolomite, calcareous

LUK_ 2

Limestones, calcareous

ZAS

Limestones, calcareous

TUR

Dolomite, calcareous

LAN

Wetterstein dolomite, calcareous

PUS

Dolomite, calcareous

VEL

Limestones, calcareous

DOL fungal ITS rDNA sequences from Psora spp. lichen thalli (KY981596 to KY9816339), and a selection of Psora spp. sequences downloaded from the GenBank. We included Protoblastenia rupestris (KT695366) as the outgroup. The second was built using newly determined fungal ITS rDNA sequences from Placidium spp. and Clavascidium spp. lichen thalli (KY981582 to KY981595), and selected sequences downloaded from the GenBank. We included Placidiopsis cinerascens (GQ344607) as the outgroup. The alignments and phylogenetic analyses were carried out as previously described for the phycobiont. The best-fit substitution model for this alignment $(\mathrm{GTR}+\mathrm{I}+\mathrm{G})$ was chosen using jModelTest v 2.0 (DARRIBA et al. 2012) and applying the Akaike Information Criterion (AKAIKe 1974, 2011).

Microscopic investigations "in thallus". Fluorescent Microscopy (FM), Transmission Electron Microscopy (TEM) and Scanning Electron Microscopy (SEM) techniques were performed for morphological analysis of symbiotic lichen microalgae. To analyse the morphology of chloroplasts in Myrmecia israeliensis inside the thalli, FM was used in the sample Psora decipiens HOM_PD_1. The chloroplast morphology was analysed by an Olympus CX21 camera with an LED Fluorescent Illuminator. Phycobionts were characterized in the samples Psora decipiens MAD_FT and Psora savizcii MAD_FT by SEM and TEM. The ultrasculpture (OsYCZKA \& Rola 2013) of the squamules was visualized by SEM. Fractured thalli were attached to the holder, coated with palladium/gold and viewed with a Hitachi (S4800). For TEM, the cells were fixed and dehydrated as described in Molins et al. (2017). Samples were embedded in Spurr's resin according to the manufacturer's instructions. Sections $(90 \mathrm{~nm})$ were cut with a diamond knife (DIATOME
Ultra $45^{\circ}$ ) using an ultramicrotome (Reichert Ultracut E), mounted on oval hole copper grids coated with formvar and post-stained with $2 \%(\mathrm{w} / \mathrm{v})$ aqueous uranyl acetate and $2 \%$ lead citrate, using the "SynapTek Grid Staining Kit" (http:// www.ems-diasum.com/microscopy/technical/datasheet/71175. aspx). The sections were observed with a JEOL JEM-1010 $(80 \mathrm{kV})$ electron microscope, equipped with a MegaView III digital camera and "AnalySIS" image acquisition software. SEM and TEM examinations were made at the SCSIE Service of the University of Valencia.

Isolation and cultivation of phycobionts. Phycobionts from selected squamules from the Fuentidueña de Tajo population (Supplementary Table 1) were isolated using the micromethod described by GaSulla et al. (2010). Samples were homogenized with a mortar and pestle in an isotonic buffer $(0.3 \mathrm{M}$ sorbitol, $50 \mathrm{mM}$ HEPES, $\mathrm{pH}$ 7.5) and filtered through muslin. Isolation was carried out by a gradient centrifugation method using Percoll ${ }^{\circledR}$. The algal suspension was diluted with sterile water, and $10 \mu \mathrm{l}$ was spread using the streak method on sterile 1.5\% agar Bold's Basal Media Petri dishes (BBM) (BoLD 1949; BISCHOFF \& BOLD 1963). The isolated algae were maintained under $15 \mu \mathrm{mol} \cdot \mathrm{m}^{-2} \cdot \mathrm{s}^{-1}$ (PPFD) for a $12 \mathrm{~h}$ photoperiod at $21^{\circ} \mathrm{C}$. Phycobionts from samples encoded as NOV, LUK1, TEM, HOM, BER, SBR and VEL (Supplementary Table 1) were isolated by the thallus fragmentation method (AHMADJIAN 1993; PeKSA \& ŠKALOUD 2008) as described in MoYA et al. (2015). After six weeks, groups of dividing algal cells were observed associated with some of the fragments. To obtain unialgal cultures, small populations of phycobionts were transferred onto the fresh BBM agar slants and incubated accordingly. 
Microscopic investigations of phycobionts "in culture". Light microscopy (LM) was performed on selected unialgal cultures obtained from Psora decipiens HOM_PD_3. For LM analyses, cultures were observed with an Olympus BX51 microscope equipped with a Canon EOS 1100D digital camera. To compare the ultrastructure obtained in symbiosis, TEM examinations were also performed on selected unialgal cultures on the $21^{\text {st }}$ day of cultivation (PEKSA \& ŠKALOUD 2008) from M. israeliensis UTEX 1181. TEM analyses were performed as previously described for the thallus.

\section{RESULTS}

Phycobiont phylogenetic analysis

A total of 57 new sequences for Psora spp., Placidium spp. and Clavascidium spp. phycobionts were obtained by Sanger sequencing from every thallus and/or isolated phycobionts cultures, and also from free-living microalgae living into gypsum crystals. All phycobionts investigated in this study (including the sequence obtained from gypsum crystals) formed a statistically well-supported clade, including a sequence of Myrmecia israelensis from UTEX 1181 (authentic strain) and four sequences generated by RUPRECHT et al. (2014) labeled as Chlorophyta spp. in the GenBank (Fig 1).

\section{Mycobiont phylogenetic analysis}

Psora decipiens and P. saviczii fungal phylogeny was constructed from 38 sequences and showed that the samples included in this study fall into six well-supported clades (Fig. 2). The fungal ITS were resolved into six clades: $P$. saviczii, $P$. decipiens s. str, Clade I, Clade II, Clade III and Clade IV. IB_CI samples were randomly distributed in the six clades, but only $P$. decipiens s. str. and Clade III appear to occur in the N_CE samples included in this study.

Placidium spp. and Clavascidium spp. fungal phylogeny was constructed, including 14 newly obtained sequences. The 14 sequences included in this study fell into five well-supported clades (Fig. 3). In the case of Placidium spp. we resolved three fungal clades (Placidium pilosellum 1, Placidium sp. 1, Placidium sp. 2), and two for Clavascidium spp. (Clavascidium sp. 2 and Clavascidium sp. 3) which appear to occur only in Iberian localities.

\section{Morphological and ultrastructural characterization} of Myrmecia israeliensis in the thallus

FM examinations of squamules from the Psora decipiens s. str. sample (HOM_PD_1) revealed the interaction between M. israeliensis and the fungal hyphae (Fig. 4), also the phycobionts showed a chloroplast characteristic of the Myrmecia genus TschermaK-Woess \& PlessL (1948). Cells showing chloroplast morphologies related to Trebouxia or Asterochloris were not detected.

To further investigate the appearance of the phycobiont layer, the SEM was employed. The phycobionts cells were located in close contact with the hyphae (Fig. 5A,
$\mathrm{B}, \mathrm{C})$. The cell wall exhibited a thickness ranging from $0.08 \pm 0.001$ to $0.18 \pm 0.003 \mu \mathrm{m}$. In the thallus, the cells showed a bipartite cup-shaped parietal chloroplast without a pyrenoid, which is characteristic of the Myrmecia genus (Fig. 5D). The thylakoid membranes were grouped in loose stacks of three to seven (Fig. 5G, H). Numerous pyrenoglobuli were distributed along the thylakoids (Fig. 5D, F, G, H). Spherical non electron-dense vesicles appeared throughout the cytoplasm and were especially numerous at the periphery (Fig. 5D, F, H). Secretory spaces were irregular in distribution and thickness.

\section{Morphological and ultrastructural characterization of Myrmecia israeliensis in culture}

Mature vegetative cells were mostly spherical as seen using LM (Fig. 6A, C). Also in culture, both with TEM and LM, the cells showed the characteristic bipartite cupshaped parietal chloroplast without a pyrenoid (Fig. 6).

\section{Discussion}

The class Trebouxiophyceae is generally known to comprise the majority of eukaryotic phycobionts (i.e. lichenized symbiotic microalgae). The genera Trebouxia Puymaly (1924), Asterochloris TschermaK-Woess (1980), Coccomyxa Schmidle (1901), Symbiochloris ŠKALOUd et al. (2016), and Myrmecia PrinTz (1921) are among the most common primary symbiotic microalgae distributed. The coccoid green alga Friedmannia israeliensis isolated as free-living from Negev desert gypsum soils was described by CHANTANACHAT \& BOLD (1962). FRIEDL (1995) demonstrated the monophyletic origin of Myrmecia astigmatica, Myrmecia biatorellae and F. israeliensis, and proposed synonymizing the genus Friedmannia with Myrmecia. Therefore, a new taxonomic combination, Myrmecia israeliensis, was proposed. These three green algae, forming a sister group with Trebouxia spp., also showed the characteristic chloroplast architecture described for Myrmecia spp.: cup-shaped, usually a lobed parietal chloroplast without a pyrenoid. However, the diversity, ecology, and distribution of Myrmecia genus as a lichen phycobiont have been overlooked in the past, and some interesting questions about this genus are still unresolved.

Studies on lichen microalgae have been performed mainly by Sanger sequencing (MoLINs et al. 2013; VoYTSEKHOVICH \& BECK 2015). However, using this procedure some results could be controversial: only the primary phycobiont could usually be detected and primer biases might limit the detection of specific taxa (U'REN et al. 2014). A combination of different techniques (molecular, isolation and microscopic) as well as the accurate selection of the molecular primers are key parameters in microalgal lichen studies and prevent any incorrect identification.

The present study contributes to the understanding 


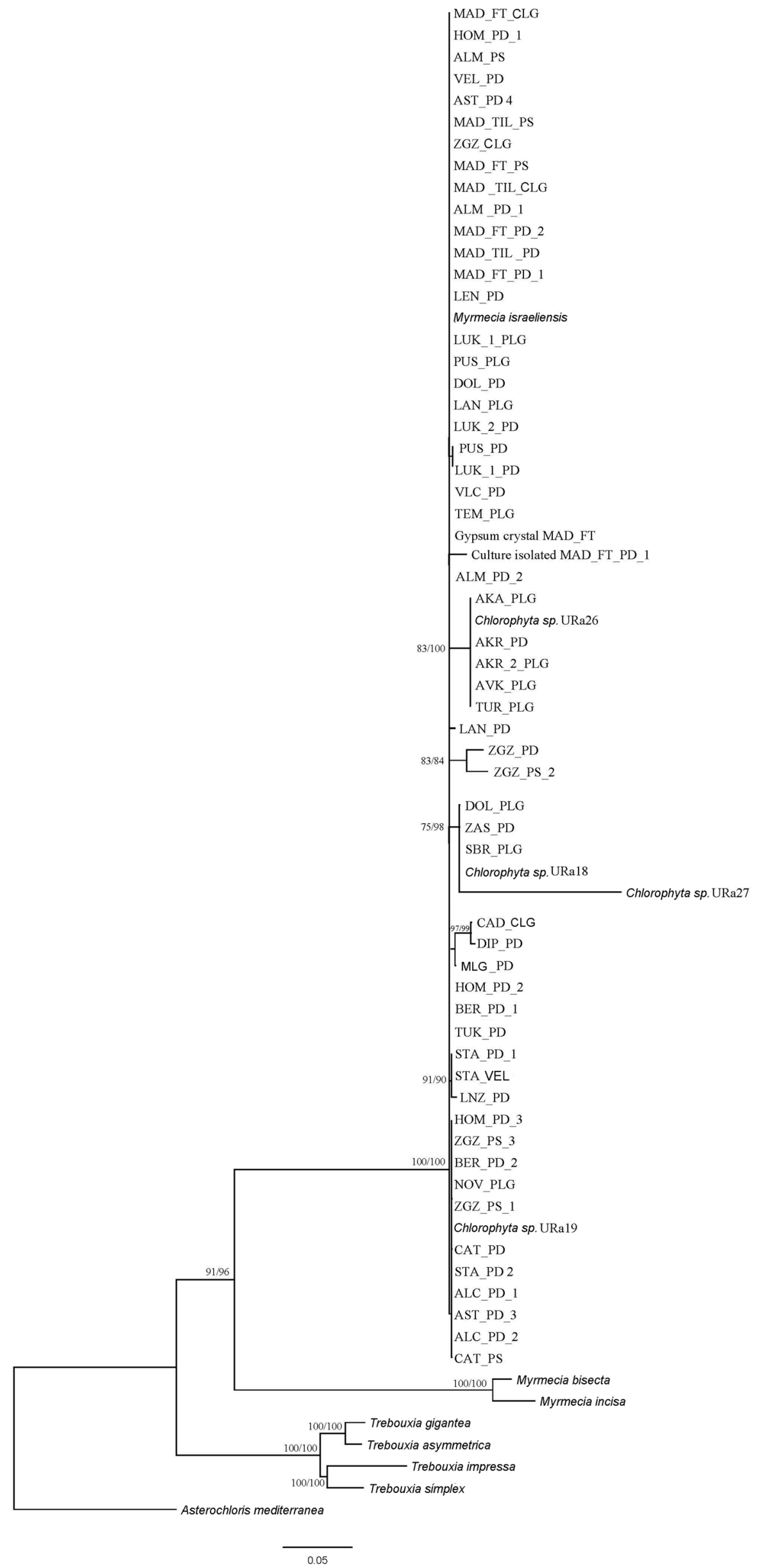




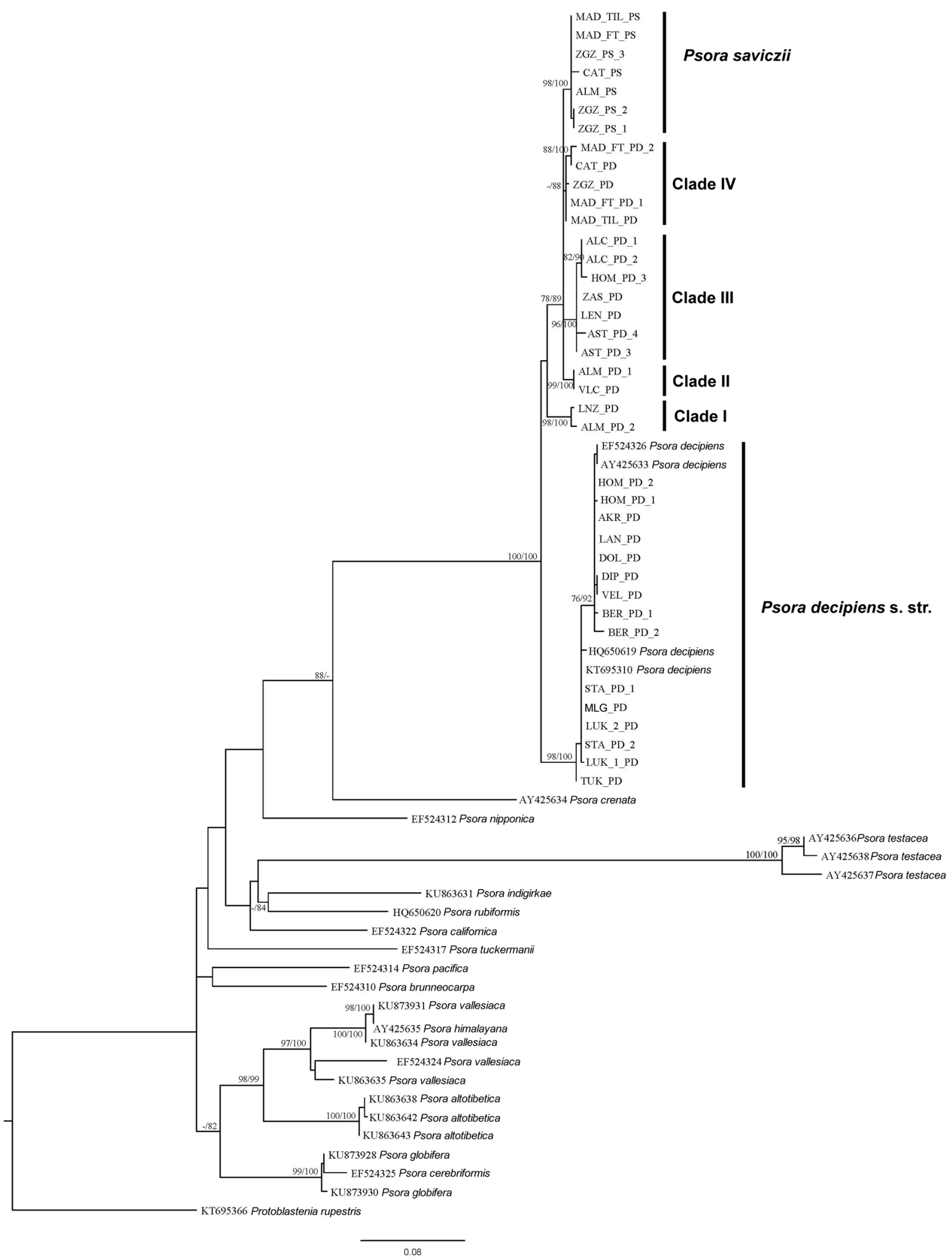

Fig. 2. Phylogenetic analysis of the ITS rDNA mycobiont from Psora spp. Values at nodes indicate statistical support estimated by two methods: MrBayes posterior node probability and maximum-likelihood bootstrap. Branches with a statistical support $\geq 75 \%$ in both analyses are indicated in the tree. Newly obtained sequences are grouped in clades named as: Psora saviczii, Psora decipiens s. str., Clade I, Clade II, Clade III and Clade IV. Accession numbers from Psora spp. and Protoblastenia rupestris sequences retrieved from the GenBank accompany each species name. Scale bar shows the estimated number of substitutions per site.

Fig. 1. Myrmecia israeliensis diversity detected by Sanger sequencing. A rooted and combined ITS rDNA and LSU rDNA gene tree representing 69 sequences is displayed, including selected sequences retrieved from the GenBank. Values at branches refer to Bayesian posterior probabilities $\geq$ to 0.75 and ML bootstrap values $\geq 75 \%$, respectively. Scale bar shows the estimated number of substitutions per site. 

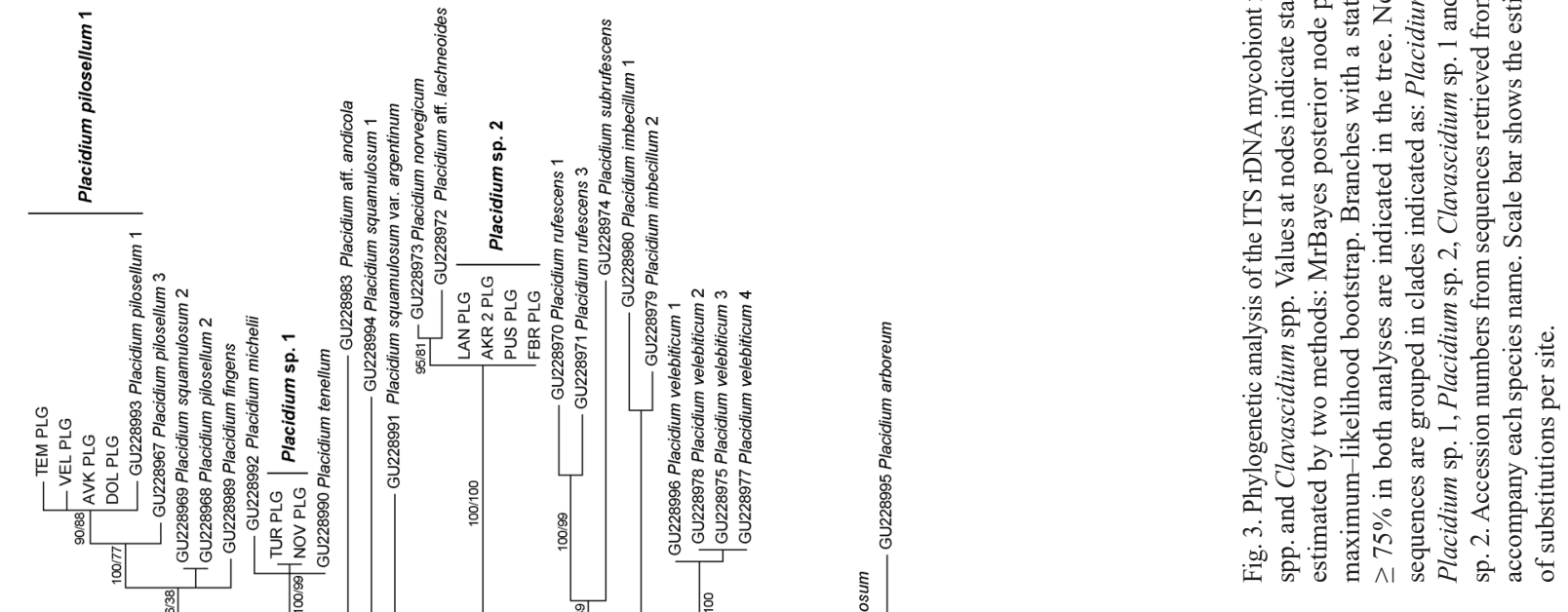

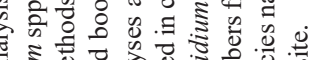

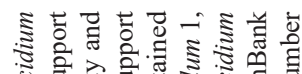

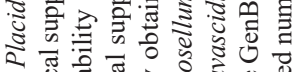

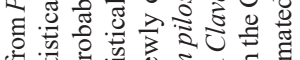

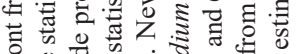

융

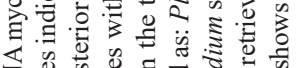

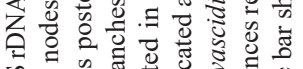

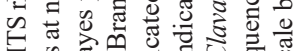

证

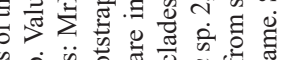

政

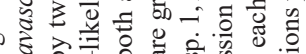

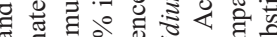

Dें

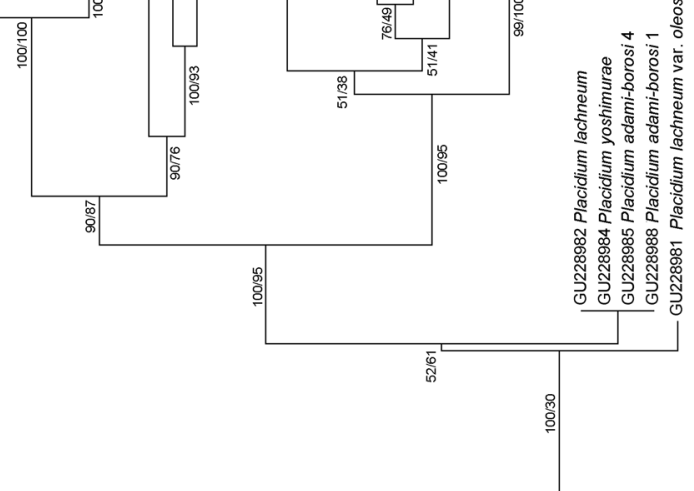

(
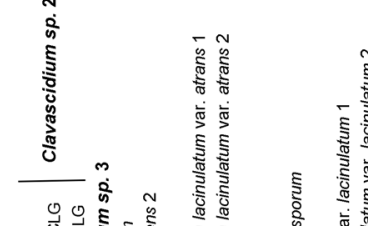

产
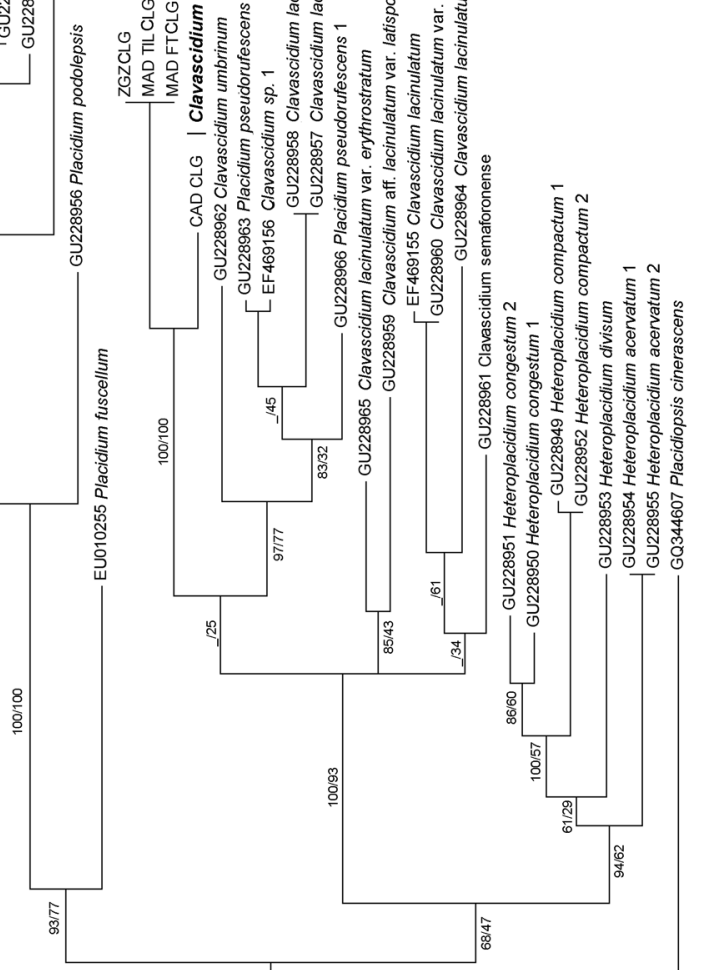

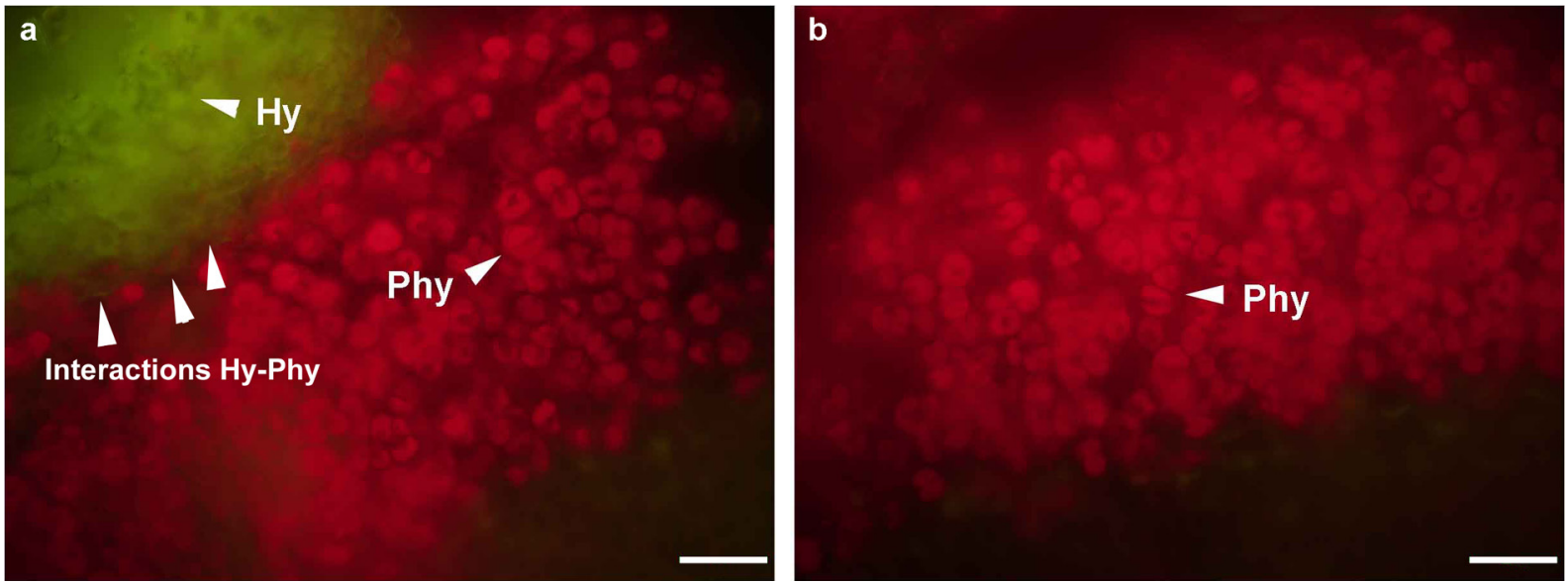

Fig. 4. Localization of Myrmecia israeliensis in squamules of Psora decipiens s. str. by FM. Abbreviations; Phy (Phycobionts) and Hy (Hyphae). Scale bar $20 \mu \mathrm{m}$.

FM examinations of squamules from the Psora decipiens s. str. sample (HOM_PD_1) revealed the interaction between M. israeliensis and the fungal hyphae (Fig. 4), also the phycobionts showed a chloroplast characteristic of the Myrmecia genus Tschermak-Woess \& PLessL 1948. Cells showing chloroplast morphologies related to Trebouxia or Asterochloris were not detected.

of the primary symbiont microalgae associated with Psora spp., Placidium spp. and Clavascidium spp. Both morphological and molecular analyses pointed out the undeniable presence of Myrmecia israeliensis linked to several terricolous squamulose lichen specimens distributed in European and Canary Island ecosystems. The nuclear ITS rDNA (clearly amplified with primers designed for this study) was added to build the algal phylogeny, together with the plastid molecular marker LSU rDNA (DEL CAMPo et al. 2010). In this work, isolation and microscopic observations on algae in both the symbiotic and the cultivated state, were crucial to corroborate the presence of $M$. israeliensis as the primary symbiotic microalga in these lichens.

All the phycobionts investigated in this study formed a statistically well-supported clade, including a sequence of the authentic strain of Myrmecia israeliensis UTEX 1181 (corroborating the determination of our sequences as M. israeliensis) and four Myrmecia sequences generated by RUPRECHT et al. (2014), who labeled them as Chlorophyta spp. These sequences were obtained by sequencing Psora lichens collected in the Ruine Homburg locality, along with numerous phycobionts determined as Trebouxia spp. and Asterochloris spp. However, our investigations, including the analysis of Psora lichens re-sampled from the Ruine Homburg locality, clearly show that neither Trebouxia nor Asterochloris were detected. Such bias can be explained by the fact that RUPRECHT et al. (2014) used highly specific primers designed in this study to amplify the Trebouxia and Asterochloris lichen phycobionts. However, these primers do not match target sites for several green algal lineages, including the genus Myrmecia. Consequently, the primary microalga Myrmecia remained undetected. Indeed, electropherograms showing double peaks and/or polymorphic phycobiont sequences have been frequently reported in lichens, but these samples were usually removed from the analysis (MugGia et al. 2014; LeAvitT et al. 2015; VOYTSEKHOVICH \& BECK 2015). In this work, we included novel and clear barcode information (ITS rDNA) which provides the basic information for a precise delimitation of the microalgae identities.

M. israeliensis was also detected by PCR as freeliving in Miocene gypsum crystals from Spain. Other lichens sharing the same habitats (BSC) with the species studied here, showed other genera as primary microalgae such as Trebouxia in: Buellia zoharyi (CHIVA et al 2015; Moya et al 2016; Muggia et al 2016), Acarospora spp., Diplotomma rivas-martinezii and Rhizocarpon malenconianum (CHIVA 2012) or Asterochloris in Cladonia spp. (MoyA et al. 2015). These results raise questions about the levels of specificity and the strategies followed by lichenized fungi to associate with a certain alga available in the substrate pool (MugGia et al. 2013; MEESSEN \& Отт, 2013; WiLLIAMs et al 2017).

Mycobiont identification was confirmed by the DNA barcoding proposed by $\mathrm{SCHOCH}$ et al. (2012) in all the specimens included in this study. TimdaL $(1984,1986)$ studied the anatomy and chemistry of Psora decipiens and $P$. saviczii, detecting several taxonomic problems at the specific level. In the European $P$. decipiens specimens he delimited three chemical strains: strain I (no lichen substances present) was the most frequent in Scandinavia and Central Europe; strain II (norstictic acid) was the most frequent in the Mediterranean region, and strain III (hyposalazinic acid and hypostictic acid) appeared in Austria, Hungary and Spain. Recently, Williams et al. (2017) included a mycobiont phylogeny (26S rDNA and $r b c \mathrm{~L}$ molecular markers) of $P$. decipiens specimens from Germany, Sweden, Spain and Austria. They also found a surprising mycobiont variability (at least four clades), but no ITS rDNA information was provided. In this work, high genetic variability was also detected (five well-supported clades), but we were not able to 

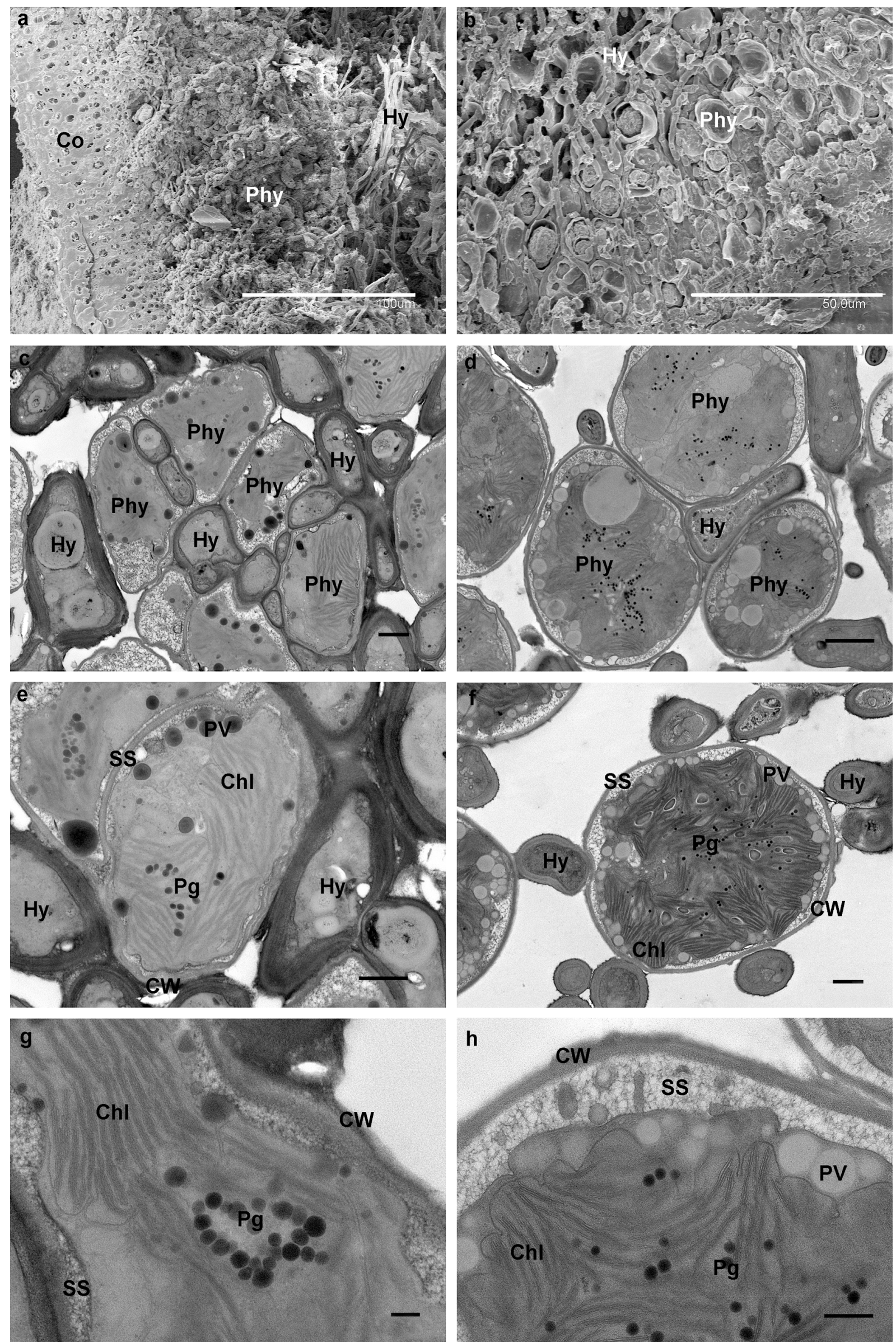

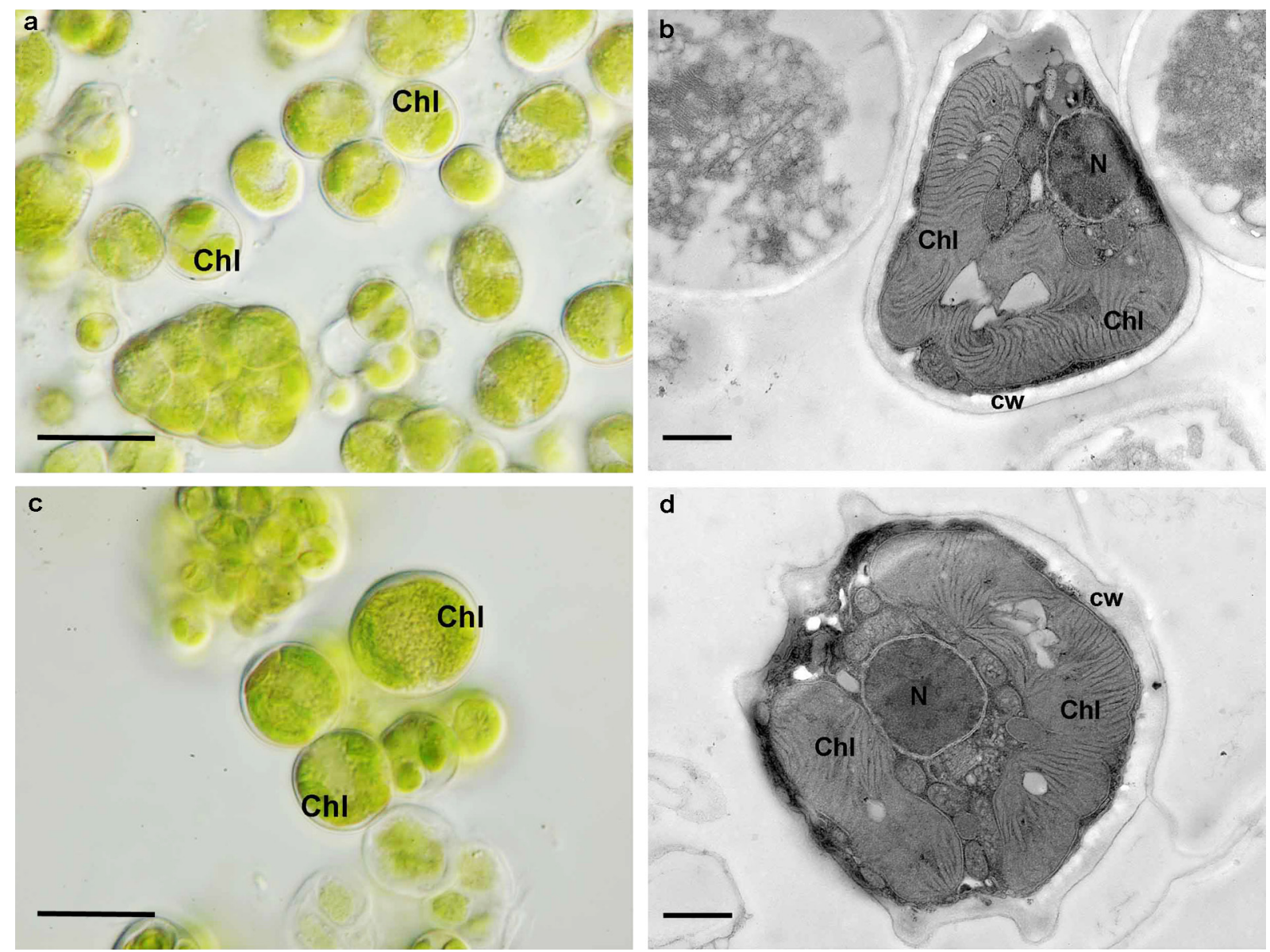

Fig. 6. Myrmecia israeliensis cells in isolated state by LM and TEM. Scale bar $800 \mathrm{~nm}$. Abbreviations; Chl (Chloroplast), N (Nucleus), CW (Cell Wall).

Fig. 5. Cross section of Psora decipiens and P. saviczii thalli, and Myrmecia israeliensis microalgae in symbiosis. A-C-E MAD_FT_PD. B-D-F MAD FT PS. G-H M. israeliensis in detail associated with these thalli. Scale bars $200 \mathrm{~nm}(\mathrm{G}), 400 \mathrm{~nm}(\mathrm{H}), 800 \mathrm{~nm}(\mathrm{E}), 1 \mu \mathrm{m}(\overline{\mathrm{C}}, \mathrm{F})$, $2 \mu \mathrm{m}$ (D), $50 \mu \mathrm{m}$ (B) and $100 \mu \mathrm{m}$ (A). Abbreviations; Phy (Phycobionts), Hy (Hyphae), Co (cortex), CW (Cell wall), SS (Secretory space), Chl (Chloroplast), Pg (Pyrenoglobuli), PV (Peripheral vesicles).

link our ITS rDNA sequences of $P$. decipiens with the sequences published by WiLliams et al. (2017) due to different analyzed loci. The advisable inclusion of chemical analyses and further research is required to understand the genetic diversity and the biogeographical distribution of $P$. decipiens.

PRIETO et al. (2012) resolved the relationships within the Placidium group (Placidium spp., Clavascidium spp. and Heteroplacidium spp.). In this work, evolutionary inference based on ITS rDNA reinforces the Placidium phylogeny suggested by PrIETo et al. (2012), and revealed four new well-supported clades, here described as Placidium sp. 1, Placidium sp. 2, Clavascidium sp. 2 and Clavascidium sp. 3.

Besides molecular techniques, $M$. israeliensis occurrence was validated in these lichen taxa through the examination of lichenized as well as isolated algae by microscopy including Transmission Electronic Microscopy (TEM). Recent literature (CASANO et al. 2011; Molins et al. 2013; CATAlá et al. 2015; Moya et al. 2015; Molins et al. 2017) proved that TEM observations should be considered as key methodology for the ultrastructural characterization of phycobiont species inside lichen thalli. The maintenance of the ultrastructural traits of the Myrmecia genus allowed us to identify and corroborate the presence of $M$. israeliensis as the primary microalga. Several authors pointed out some ultrastructural modifications when comparing isolated phycobionts $v s$ lichenized states (e. g. cell wall thickness and the amount of mitochondria and ribosomes) (GALUN 1988; FRIEDL \& BüDel 2008; MelKonian \& Berns 1983). Despite this, ultrastructural characteristic traits of cells from the Myrmecia genus remained recognizable enough in culture to allow for the correlation of both states (symbiotic and isolated).

In summary, our results proved M. israeliensis to be the primary symbiotic microalga in all the lichens analyzed here, and the presence of this microalga was verified using different molecular and microscopic observations. The combination of different techniques, molecular, isolation and microscopic, allowed for the accurate identification of this symbiotic microalga, 
previously mainly known as free living.

\section{ACKNOWLEDGEMENTS}

Supported by the Ministerio de Economía y Competitividad (MINECO, Spain) (CGL2016-79158-P), Excellence in Research (Generalitat Valenciana, Spain) (PROMETEOI/2013/021 ; PROMETEO/2017/039), the Czech Science Foundation (GP13-39185P), and the Primus Research Programme of Charles University (SCI/13). We want to thank the technicians ( $\mathrm{M}^{\mathrm{a}}$ Teresa Mínguez and Nuria Cebrián) of the Servicio de Microscopía Electrónica, SCSIE and Jardí Botànic (Universitat de València) who helped us to perform the TEM process. Daniel Sheerin revised the English manuscript.

\section{REFERENCES}

Ahmadjian, V. (1993): The lichen symbiosis. - John Wiley \& Sons, New York.

AKaIKe, H. (1974): A new look at the statistical model identification. - IEEE transactions on automatic control 19: 716-723

AkAIKe, H. (2011): Akaike's information criterion. - In: HeIdelberG, S. B. (ed.): International Encyclopedia of Statistical Science. - pp. 25-25, Springer, Berlin.

Arnold, A.E.; MiadlikowsKa, J.; Higgins, K.L.; SARVATE, S.D.; GugGer, P.; Way, A.; Hofstetter, V.; Kauff, F. \& Lutzoni, F. (2009): A phylogenetic estimation of trophic transition networks for ascomycetous fungi: Are lichens cradles of symbiotrophic fungal diversification? - Syst. Biol. 58: 283-297.

BelnaP, J. \& LANGE, O.L. (2001): Structure and functioning of biological soil crusts: A synthesis. - In: BeLNAP, J. \& LANGE, O.L. (eds): Biological soil crusts: structure, function, and management. - pp. 471-479, Springer, Berlin.

Belnap, J. (2003): The world at your feet: Desert biological soil crusts. - Front. Ecol. Environ. 1: 181-189.

BELnAP, J. \& BÜDEL, B. (2016): Biological soil crusts as soil stabilizers. - In: WEBER, B.; BELNAP, J. \& BÜDEL, B. (eds): Biological Soil Crusts: An Organizing Principle in Drylands. - pp. 305-320, Springer, Berlin.

Bischoff, H.W. \& Bold, H.C. (1963): Phycological studies IV. Some soil algae from enchanted rock and related algal species. - 95 pp., Publications No. 6318, University of Texas.

BoLD, H.C. (1949): The morphology of Chlamydomonas chlamydogama, sp. nov. - Bulletin of the Torrey Botanical Club 76: 101-108.

Bowker, M.A.; MaU, R.L.; Maestre, F.T.; Escolar, C. \& Castillo-Monroy, A.P. (2011): Functional profiles reveal unique ecological roles of various biological soil crust organisms. - Funct. Ecol. 25: 787-795.

Büdel, B.; Colesie, C.; Green, T.A.; Grube, M.; SuAu, R.L.; Loewen-Schneider, K.; Maier, S.; Peer, T.; Pintado, A. \& RAGGIO, J. (2014): Improved appreciation of the functioning and importance of biological soil crusts in Europe: The soil crust international project (SCIN). - Biodivers. Conserv. 23: 1639-1658.

Casano, L.M.; DEl CAMPO, E.M.; García-BreiJo, F.J.; ReIGArmiñana, J.; Gasulla, F.; Del Hoyo, A.; Guéra, A. \& BARreno, E. (2011): Two Trebouxia algae with different physiological performances are ever present in lichen thalli of Ramalina farinacea. Coexistence versus competition? - Environ. Microbiol. 13: 806-818.
Castresana, J. (2000): Selection of conserved blocks from multiple alignments for their use in phylogenetic analysis. - Mol. Biol. Evol. 17: 540-552.

Catalá, S.; del Campo, E.M.; Barreno, E.; García-Breijo, F.J.; Reig-Armiñana, J. \& Casano, L.M. (2015): Coordinated ultrastructural and phylogenomic analyses shed light on the hidden phycobiont diversity of Trebouxia microalgae in Ramalina fraxinea. - Mol. Phylogenet. Evol. 94: 765-777.

Chantanachat, S. \& Bold, H.C. (1962): Phycological studies II. Some algae from arid soils. -74 pp., Publications No. 6218, University of Texas.

CHIVA, S. (2012): Especificidad y variabilidad de los ficobiontes identificados en líquenes de comunidades gipsícolas. -68 pp., Master Dissertation, Universitat de València, Spain.

Chiva, S.; Moya, P.; Molins, A.; Reig-Armiñana, J.; GarcíaBReIJo, F.J. \& BARRENo, E. (2015): Coexistence and prevalence of symbiotic microalgae in Buellia zoharyi lichen: are substrata and/or biogeographic barriers involved? - In: Costa Vieira; Pinto Hespanhol; Mendonça Marques; Vasconcelos \& Arenas (eds): XX Simpósio de Botânica Criptogâmica. - pp.60, CIIMAR- CIBIO/InBIO, Oporto, Portugal. ISBN: 978-989-97443-5-6.

Darriba, D.; Taboada, G.L.; Doallo, R. \& Posada, D. (2012): jModelTest 2: More models, new heuristics and parallel computing. - Nat. Methods 9: 772-772.

Del Campo, E.; Casano, L.; Gasulla, F. \& Barreno, E. (2010): Suitability of chloroplast LSU rDNA and its diverse group I introns for species recognition and phylogenetic analyses of lichen-forming Trebouxia algae. - Mol. Phylogenet. Evol. 54: 437-444.

Doyle, J. \& Doyle, J. (1987): Genomic plant DNA preparation from fresh tissue-CTAB method. - Phytochem. Bull. 19: 11-15.

FRIEDL, T. (1995): Inferring taxonomic positions and testing genus level assignments in coccoid green lichen algae: A phylogenetic analysis of $18 \mathrm{~S}$ ribosomal RNA sequences from Dictyochloropsis reticulata and from members of the genus Myrmecia (Chlorophyta, Trebouxiophyceae cl. nov.) 1. - J. Phycol. 31: 632-639.

FRIEDL T. \& BÜDEL B. (2008): Photobionts. - In: NASH, T. H. (eds): Lichen biology. - pp. 9-26, Cambridge University Press, Cambridge.

Galun, M.; Ben-Shaul, Y. \& Paran, N. (1971): The fungusalga association in the Lecideaceae: An ultrastructural study. - New Phytol. 70: 483-485.

GALUN, M. (1988): CRC handbook of lichenology. Vols I-III. - CRC Press, Boca Raton, FL, USA.

GARDES, M. \& BRUNS, T.D. (1993): ITS primers with enhanced specificity for basidiomycetes-application to the identification of mycorrhizae and rusts. - Mol. Ecol. 2: $113-118$

Gasulla, F.; GuÉra, A. \& Barreno, E. (2010): A simple and rapid method for isolating lichen photobionts. Symbiosis 51: 175-179.

GeitLER, L. (1963): Über haustorien bei flechten und über Myrmecia biatorellae in Psora globifera. - Plant Syst. Evol. 110: 270-280.

KatoH, K.; Misawa, K.; Kuma, K. \& MiYATA, T. (2002): MAFFT: A novel method for rapid multiple sequence alignment based on fast fourier transform. - Nucleic Acids Res. 30: 3059-3066

KatoH, K. \& STANDLEY, D.M. (2013): MAFFT multiple sequence 
alignment software version 7: Improvements in performance and usability. - Mol. Biol. Evol. 30: 772-780.

Leavitt, S.D.; KraichaK, E.; Nelsen, M.P.; Altermann, S.; DivaKar, P.K.; Alors, D.; EsSLinger, T.L.; CresPo, A. \& LumbSCH, T. (2015): Fungal specificity and selectivity for algae play a major role in determining lichen partnerships across diverse ecogeographic regions in the lichen-forming family Parmeliaceae (Ascomycota). - Mol. Ecol. 24: 3779-3797.

Maestre, F.T.; Bowker, M.A.; Cantón, Y.; Castillo-Monroy, A.P.; Cortina, J.; Escolar, C.; Escudero, A.; LÁzaro, R. \& MARTínEZ, I. (2011): Ecology and functional roles of biological soil crusts in semi-arid ecosystems of Spain. - J. Arid Environ. 75: 1282-1291.

Meessen, J., \& OTt, S. (2013). Recognition mechanisms during the pre-contact state of lichens: I. Mycobiontphotobiont interactions of the mycobiont of Fulgensia bracteata. - Symbiosis 59: 121-130.

Melkonian, M. \& Berns, B. (1983): Zoospore ultrastructure in the green alga Friedmannia israelensis: An absolute configuration analysis. - Protoplasma 114: 67-84.

Miller, M. A.; Pfeiffer, W. \& Schwartz, T. (2010): Creating the CIPRES Science Gateway for inference of large phylogenetic trees. - In: Gateway Computing Environments Workshop (GCE), 2010 November.

Molins, A.; García-Breijo, F.J.; Reig-Armiñana, J.; Del Campo, E.; Casano, L. \& Barreno, E. (2013): Coexistence of different intrathalline symbiotic algae and bacterial biofilms in the foliose Canarian lichen Parmotrema pseudotinctorum. - Vieraea 41: 349-370.

Molins, A.; Moya, P.; García-Breijo, F.J.; Reig-Armiñana, J. \& BARRENO, E. (2017): A multi-tool approach to assess microalgal diversity in lichens: isolation, Sanger sequencing, HTS and ultrastructural correlations. - The Lichenologist. doi:10.1017/S0024282917000664.

Moya, P.; ŠKaloud, P.; Chiva, S.; García-Breijo, F.J.; ReigArminanA, J.; VANČURoví, L. \& BARRENO, E. (2015): Molecular phylogeny and ultrastructure of the lichen microalga Asterochloris mediterranea sp. nov. from Mediterranean and Canary Island ecosystems. - Int. J. Syst. Evol. Microbiol. 65: 1838-1854.

Moya, P.; Chiva, S.; Molins, A.; Reig-Armiñana, J.; GarcíaBREIJO, F.J. \& BARRENO, E. (2016): Improved propagation method, rapid molecular identification and ultrastructural characterization as a multidisciplinary approach for Trebouxia species delimitation. - In: Meeting of the TREBOUXIA-WORKING group, September 2016 (http://www.symbioticgreenalgae.com/).

Muggia, L.; Vančurová, L.; ŠKaloud, P.; Peksa, O.; Wedin, M. \& GRUBE, M. (2013): The symbiotic playground of lichen thalli-a highly flexible photobiont association in rock-inhabiting lichens. - FEMS Microbiol. Ecol. 85: 313-323.

Muggia, L.; PéreZ-Ortega, S.; Kopun, T.; Zellnig, G. \& Grube, M. (2014): Photobiont selectivity leads to ecological tolerance and evolutionary divergence in a polymorphic complex of lichenized fungi. - Ann. Bot. 114: 463-475.

Muggia, L.; Leavitt, S. \& Barreno, E. (2016): Report of the meeting of the trebouxia-working group. - International lichenological newsletter 49:35-37

Osyczka, P. \& Rola, K. (2013): Phenotypic plasticity of primary thallus in selected Cladonia species (lichenized Ascomycota: Cladoniaceae). - Biologia 68: 365-372.

Peksa, O. \& ŠKaloud, P. (2008): Changes in chloroplast structure in lichenized algae. - Symbiosis (Rehovot) 46: $153-160$.

Pointing, S.B. \& BelnaP, J. (2012): Microbial colonization and controls in dryland systems. - Nat. Rev. Microbiol. 10: $551-562$.

Prieto, M.; Martínez, I.; Aragon, G.; Gueidan, C. \& Lutzoni, F. (2012): Molecular phylogeny of Heteroplacidium, Placidium, and related Catapyrenioid genera (Verrucariaceae, lichen-forming ascomycota). - Am. J. Bot. 99: 23-35.

Printz, H. (1921): Subaerial algae from South Africa. - Kong. Norsk. Vidensk. Selsk. Skrift. 1: 3-41.

Puymaly, A. (1924): Recherches sur les algues vertes aériennes. - 274 pp., Thés. Fac. Sci. Univ. of Paris, Ser. A. N 991, Bordeaux.

Rambaut, A. (2014): FigTree 1.4.2 software. Institute of Evolutionary Biology, Univ. Edinburgh.

Ronquist, F.; Teslenko, M.; van der Mark, P.; Ayres, D.L.; Darling, A.; Hohna, S.; Larget, B.; Liu, L.; Suchard, M.A. \& HuELSENBECK, J.P. (2012): MrBayes 3.2: Efficient bayesian phylogenetic inference and model choice across a large model space. - Syst. Biol. 61: 539-542.

ROSENTRETER, R. (2007): Biotic soil crust lichens of the Columbia Basin. - Faculty Authored Books. 137. Northwest Lichenologists. Corvallis. http://scholarworks.boisestate.edu/fac books/137

RUPRECHT, U.; BRUNAUER, G. \& TÜRK, R. (2014): High photobiont diversity in the common European soil crust lichen Psora decipiens. - Biodivers. Conserv. 23: 1771-1785.

SCHAPER, T. \& OTT, S. (2003): Photobiont selectivity and interspecific interactions in lichen communities. I. culture experiments with the mycobiont Fulgensia bracteata. - Plant Biol. 5: 441-450.

Schmidle, W. (1901): Ueber drei algen genera. - Ber. Dtsch. Bot. Ges. 19: 10-24.

SChOCh, C.L.; SeIFERT, K.A.; Huhndorf, S.; Robert, V.; SPOUge, J.L.; Levesque, C.A.; Chen, W.; Fungal Barcoding CONSORTIUM \& Fungal Barcoding CONSORTIUM Author LIST. (2012): Nuclear ribosomal internal transcribed spacer (ITS) region as a universal DNA barcode marker for fungi. - Proc. Natl. Acad. Sci. U.S.A. 109: 6241-6246.

ŠKaloud, P., Friedl, T., Hallmann, C., Beck, A. \& Dal Grande, F. (2016): Taxonomic revision and species delimitation of coccoid green algae currently assigned to the genus Dictyochloropsis (Trebouxiophyceae, Chlorophyta). -J. Phycol. 52: 599-617.

Stamatakis, A.; Hoover, P. \& Rougemont, J. (2008): A rapid bootstrap algorithm for the RAxML web servers. Syst. Biol. 57: 758-771.

StAMATAKIS, A. (2014): RAxML version 8: A tool for phylogenetic analysis and post-analysis of large phylogenies. - Bioinformatics 30: 1312-1313.

Thüs, H.; Muggia, L.; Pérez-Ortega, S.; FaVero-Longo, S.E.; JoNeSON, S.; O’Brien, H.; NelSEN, M.P.; DuQUe-ThüS, R.; Grube, M. \& FrIEDL, T. (2011): Revisiting photobiont diversity in the lichen family Verrucariaceae (Ascomycota). - Eur. J. Phycol. 46: 399-415.

Timdal, E. (1984): The delimitation of Psora (Lecideaceae) and related genera, with notes on some species. - Nord. J. Bot. 4: 525-540.

Timdal, E. (1986): A revision of Psora (Lecideaceae) in North America. - Bryologist 253-275.

Tschermak-Woess, E. \& Plessl, A. (1948): Über zweierlei typen der sukzedanen teilung und ein auffallendes 
teilungsverhalten des chromatophors bei einer neuen protococcale, Myrmecia pyriformis. - Österr. Bot. Z. 95: 194-207.

TsCHERMAK-Woess, E. (1980): Asterochloris phycobiontica, gen. et spec. nov., der phycobiont der Flechte Varicellaria carneonivea. - Plant Syst. Evol. 135: 279-294.

TSCHERMAK-Woess, E. (1988): The algal partner. In: GALUN $\mathrm{M}$ (eds): CRC handbook of lichenology, vol. 1. - pp. 39-94, CRC Press, Boca Raton, FL, USA.

U’Ren, J.M.; Riddle, J.M.; Monacell, J.T.; Carbone, I.; MiadlikowsKa, J. \& ARnold, A.E. (2014): Tissue storage and primer selection influence pyrosequencing-based inferences of diversity and community composition of endolichenic and endophytic fungi. - Mol. Ecol. Res. 14: 1032-1048.

VoytsekHovich, A. \& Beck, A. (2015): Lichen photobionts of the rocky outcrops of Karadag massif (Crimean Peninsula). - Symbiosis 68: 9-24.

Weber, B.; Belnap, J. \& Büdel, B. (2016): Biological Soil Crusts: An Organizing Principle in Drylands. - 549 pp., Springer-Verlag, Berlin.

White, T.J.; Bruns, T.; LeE, S. \& TAYLOR, J. (1990): Amplification and direct sequencing of fungal ribosomal RNA genes for phylogenetics. - PCR protocols: a guide to methods and applications 18: 315-322.

Williams, L.; Colesie, C.; Ullmann, A.; Westberg, M.; Wedin, M. \& BÜDEL, B. (2017): Lichen acclimation to changing environments: Photobiont switching vs. climate-specific uniqueness in Psora decipiens. - Ecology and Evolution 7: 2560-2574.

Supplementary material

the following supplementary material is available for this article:

Table S1. GenBank accession number for specimens and culture included in this study.

This material is available as part of the online article (http:// fottea.czechphycology.cz/contents)

(C) Czech Phycological Society (2018)

Received June 20, 2017

Accepted October 10, 2017 